\title{
The Effect of Guided Writing Strategy on Improving the Writing of Saudi English as a Foreign Language Students
}

\author{
Khalid M. Alwahibee
}

\author{
Imam Mohammed Bin Saud Islamic University
}

Abstract

This study was an attempt to investigate the effect of using guided writing strategy on Saudi English as a foreign language students' writing. For this study, a quasiexperimental design was used. Sixteen students of the third level in the English Language and Literature Department at the College of languages and translationImam Mohammed bin Saud University participated in this study. They were enrolled in the essay writing course. The experiment involved a pretest and a posttest exam. The same group was taught using the traditional approach for 8 weeks, followed by using the guided writing strategy for the last 4 weeks. The results of both the pre- and posttest and the attitude questionnaire were analyzed. The results revealed that there was a significant difference in students' performance, which showed improvement. The statistical results were confirmed by the students' responses to the questionnaire. All students indicated that they benefited from the use of this strategy. Thus, it is recommended that teachers encourage students to use the guided writing template found on the website of the assigned book to help them improve their writing. Other recommendations are also presented. Finally, future research directions are suggested to confirm the results of this study.

Keywords: Guided, Strategy, Template, Technique

Writing is an important communication skill. However, it is considered the most difficult complex skill for English as a foreign language (EFL) learners (Irawati, 2015). It is a productive skill that requires a student to put his or her ideas and thoughts into writing to express his or her needs to his or her audience. Writing is the least used form of communication by students to communicate with each other and with other people. It is easy to say words or sentences orally, but it is difficult to put a string of words into writing and make it very convincing or thought provoking. Hyland (2003) believed that it was painstaking for EFL learners to write in the target language.

Many studies have investigated strategies to enhance writing for EFL learners. Among these strategies are modelling, guided pictures, sentence rearrangement, shared writing, and guided writing. Guided writing focuses on the process of writing. It gives clues for the students to follow in order to compose a piece of writing (Harmer, 2004). The Ontario Education (2005) guide stated that guided writing provides learners with a checklist to review what they write in a small group setting and then to apply this strategy independently later on.

Guided writing offers great chances for learners to follow steps to complete a task by connecting parts of a paragraph or essay. Holdich and Chung (2003) indicated that when students follow these steps, they will 
make valuable connections between words and sentences in a text. Guided writing focuses on the process of writing rather than the product of writing. The Ontario Education (2005) guide mentioned that the teacher plays the role of the facilitator to help students build their essays step by step and discover what they want to say and how to say it. In this process, the teacher and students work together to build the essay, beginning with the main idea, followed by developing the introductory paragraph, body paragraphs, and conclusion.

The poor writing ability of students at the university level has become very obvious to essay writing teachers. This paper will provide a further step for the guided paragraph. Students will use a template found in the textbook assigned for the level-three essay writing class. They will be guided to write their essays using this template to examine the effect of guided writing activities on improving the writing of Saudi EFL students.

\section{Statement of the Problem}

The writing process has been claimed to be difficult for EFL students. Saudi students are not different from other non-native students. Saud (2015) stated that "writing is the most difficult skill to master. Saudi students of English find it very difficult to construct a coherent written essay in English" (p. 1). She also determined the areas of difficulty, saying that "the difficulties lie not only in the poor organization, the inappropriate thesis statement, the inadequacy of providing examples and details, the limited vocabulary but also the misuse of cohesive devices" (Saud, 2015, p. 1). Most Saudi learners start writing a paragraph in level one. However, when it comes to composing an essay, they write very poorly in terms of content, vocabulary, sentence structure, and use of transitions and connectors. There might be many reasons for these problems, yet helping students in the writing process and checking its effect was not previously investigated for Saudi EFL learners only. Guided writing was proven to be very effective in many studies involving learners from other nations (Lan, Hung, \& Hsu, 2011; Lili, 2015). Through teaching essay writing for several semesters, I came to know that Saudi learners have lots of problems when composing an essay. Most of their difficulties are not due to lack of words but rather with building the idea, following the essay structure, use of transitions and connectors, and writing the conclusion paragraph. Therefore, this research will investigate the effect of using guided writing strategies to help Saudi learners improve their essay writing.

\section{Purpose of the Study}

The purpose of this study was to investigate the effect of helping students accomplish their writing by using a strategy other than the traditional way of teaching essay writing. The study will also examine the 


\section{Dr. Khalid M. Alwahibee}

effect of using a special template that was neglected by the students, which is found in the electronic page of the assigned book. Moreover, it will show both the learners and the teacher the importance of referring to and using the Web page of the book.

\section{Significance of the Study}

It is expected that the results of the study will show how important it is to follow the guidelines of the assigned book for both teachers and learners. It will also present a new way of teaching essay writing to thirdlevel students.

\section{Research Questions}

The following are the research questions of this study:

- Is there any positive effect of using the guided writing template strategy on the performance of third-level essay writing students?

- If there were any positive effect on students' performance, how significant would it be?

- Is there any positive effect on students' attitudes toward the use of guided writing strategy?

- Which part of students' essay writing is affected by this strategy?

\section{Literature Review}

Language is a means of communication between people (Amberg $\&$ Vause, 2010). In this sense, Weigle (2002) defined the process of writing as "an act that takes place within context, that accomplishes a particular purpose, and that is appropriately shaped for its intended audience" (p. 19). As a result of knowing the process, students are expected to develop their ability in writing a good paragraph or essay. There are various types of guided writing, especially for public school students. Lidvall (2008) believed that writing is an important part of the elementary school curriculum that requires special training. In a previous study, Lee (1994) pointed out the importance of using pictures as a guided writing technique, which proved to be very effective in helping students in the writing process and improved their writing proficiency. Other studies investigated the effect of using technology on the writing of elementary students (Yang, Ko, \& Chung, 2005).

For students to be creative, they need to be aware of the writing process they go through when writing. Brown (2001) said

a good deal of attention was placed on "model" composition that students would emulate and on how well a student's final product measured up against a list of criteria that included content, organization, vocabulary use, grammatical use, and mechanical consideration such as spelling and punctuation. (p. 335)

Anggara (2013) interpreted that by saying that placing a "focus on the process does not mean that the result of writing is not important. The final 

(p. 9). Holdich and Chung (2003) assumed that guided writing offers greater opportunities for young writers to make valuable connections between text, sentence, and word level. The use of the guided writing strategy can help learners form and rewrite texts with particular criteria in mind. It includes helping the learner through the various stages of the writing process to complete the task.

Some researchers investigated the effectiveness of using the guided writing strategy on students' writing performance. Lan, Hung, and Hsu (2011) examined the effect of various guided writing strategies based on the media richness theory on younger students' writing attitudes in terms of motivation, enjoyment, and anxiety. The results showed that the rich media guided writing strategy had a higher significant difference than pen-and-paper guided writing in terms of writing attitude motivation, enjoyment, and anxiety. Furthermore, the findings implied that providing a Web-based learning environment with high-richness media could guide students to write and achieve more positive attitudes in terms of motivation, enjoyment, and anxiety. Timayi (2015) found that there was a significant difference in the mean achievement score in favor of the experimental group for whom the guided writing strategy was used. Finally, Anggara (2013) revealed that there was a significance difference in writing ability in favor of the experimental group for whom the guided writing strategy was used over those form whom a conventional technique was used. He concluded that the use of the guided writing technique significantly improved students' English writing ability in Grade 8.

\section{Methodology}

\section{Research Design}

A quasi-experimental design was used for this study. The study involved a pretest and posttest for the same group. Qualitative analysis was used to investigate and describe the attitudes of students regarding the use of the guided writing strategy. Quantitative analysis was used to examine the effectiveness of using the guided writing strategy on students' writing.

\section{Sample}

The sample of the study comprised 21 third-level students studying English as a major in the English Department at the college of languages and translation at Imam Mohammed bin Saud Islamic University. They voluntarily participated in this study. They were studying English 211 (essay writing). 


\section{Instruments}

\begin{tabular}{|l|l|l|}
\hline \multicolumn{2}{|l|}{ Reliability Statistics } \\
\hline Test & $\begin{array}{l}\text { Cronbach's } \\
\text { Alpha }\end{array}$ & N of Items \\
\hline Test & .723 & 5 \\
\hline
\end{tabular}

Two instruments were used for this research. A pre-essay writing test was conducted to measure the level of students' writing before the experiment. A post-essay writing test was administered at the end of the 4 weeks of practice with the guided writing strategy. Furthermore, an attitude questionnaire was used to determine students' opinions about the use of the guided writing strategy.

\section{Validity of the Post-Essay Writing Test}

The post-essay writing test was sent to two teachers, a male and a female, who were currently teaching the course to other classes during the time of the experiment. They evaluated the question instructions as well as the topic choice and the number of words students' were supposed to write. They indicated that it was very appropriate for the level and the opinion essay content being taught in the course at the time of the experiment.

\section{Reliability of Post-Essay Writing Test}

To check the reliability of the post-essay writing test, the guided writing strategy was administered to a group of 11 students. They were trained on how to use the guided writing template to write their essays. At the end of this piloting, they were given a topic about which to write an essay following the same strategy they had used during the semester. The evaluation criteria of the essay were adopted from the assigned book (The Short Essay: Effective Academic Writing, 2nd ed., by Alice Savage and Patricia Myer). The results were measured using Cronbach's alpha. The reliability statistics are presented in Table 1.

Table 1

\section{Cronbach's Alpha for the Essay Writing Pilot Test}

From Table 1, it is clear that 0.723 is statistically accepted because it is higher than 0.60 (Abu Hashim, 2003).

\section{Validity of Attitude Questionnaire}

The questionnaire was presented to the same teachers. They said that all 10 statements covered all intended techniques used in this course. They indicated that all statements were clear and appropriate.

\section{Reliability of Questionnaire}

The researcher involved the same students who participated in the pilot study. The researcher explained what a guided paragraph was, how 
the students should use it, and why students should use it. He answered all inquiries they had about the guided writing strategy. After training them on how to write an essay using the guided writing template, he distributed the questionnaire to the students. The results were calculated using Cronbach's alpha.

Table 2

Cronbach's Alpha for the Attitude Questionnaire

\begin{tabular}{|l|l|l|}
\hline \multicolumn{2}{|l|}{ Reliability Statistics } \\
\hline Test & $\begin{array}{l}\text { Cronbach's } \\
\text { Alpha }\end{array}$ & N of Items \\
\hline Attitude & .886 & 10 \\
\hline
\end{tabular}

From Table 2, it is clear that 0.886 is statistically accepted because it is higher than 0.60 (Abu Hashim, 2003).

\section{Procedures}

Level-three students taking English 211 (essay writing course) participated in this study. The researcher was the teacher of this course. At the beginning of the course, he obtained students' permission to apply the guided writing strategy during the last 4 weeks of the course.

The course began with 21 students and ended with 16 students. The teacher used the traditional way of teaching, following the outline of the chapters. Students had to work on three types of essays. They learned how to write compare and contrast essays, opinion essays, and cause and effect essays. One chapter was devoted to each type. The outline of the course contained two main goals: the rhetorical focus, which refers to the organization of the essay, and the language and grammar focus, which refers to the use of writing elements, such as connectors and comparatives. In other chapters, the two main goals referred to different aspects, such as facts, counterarguments and refutations, and quantity expressions in opinion essays or how to cluster information and use of phrasal verbs and if clauses in cause and effect essays. For each chapter, the teacher worked with the students on all exercises in the book and analyzed all essays in all chapters. Students were asked to write two essays for each chapter. They had three midterms, one for each type of essay.

Before the end of the semester, for about four weeks, the teacher introduced the strategy to the students. Unfortunately, none of the students used the online access for the exercises they worked on. The teacher asked them many times to do so, but none did. Therefore, the teacher used the overhead projector and showed them the template they 


\section{Dr. Khalid M. Alwahibee}

were supposed to work on for the last 4 weeks (see Appendix A). The teacher reminded them that they would write two essays for every lecture. For the first one, the teacher walked around the class and helped each student by explaining and helping them to follow the guidelines of the template. For the first week of the experiment, the students were asked to write a compare and contrast essay. During the second meeting, they were told to practice writing an opinion essay using the guided writing template. Similarly, the teacher walked around and helped each student follow the guidelines. If they did not follow the guidelines, he asked them to go back and work on them. For the second try, he did not help the students; rather, he watched them. Similarly, they practiced the third type of essay they had worked on during the semester. During the last week, they were presented with the test without the guided writing template. They were asked to write an opinion essay with the following prompt: "Many places are famous and attract a lot of tourists, but tourism changes these places. Is tourism good for a town?"

The main intention of the researcher in using the guided writing template was to develop five main aspects of students' writing: writing essays that effectively responded to the writing prompt; writing wellorganized essays with an introduction, body paragraphs, and a conclusion; supporting their topic sentences properly; using proper grammar, spelling, and punctuation; and using connectors and transitional words appropriately. All these guidelines were provided to the students in the template as reminders for the students when doing the writing task.

\section{Results}

\section{First Hypothesis}

There was no significant difference $(\alpha \leq .05)$ in the mean scores of the students in the group before and after the experiment that may be interpreted as being due to the use of the guided writing strategy.

To test this hypothesis, a paired-sample $t$ test was performed to identify any significant differences in the two mean scores for both tests, before and after the experiment, for the same group. Table 3 shows the results.

Table 3

Paired-Sample T Test for the Mean Scores of the Students in the Writing Pre- and Posttest

\begin{tabular}{|l|l|l|l|l|l|l|l|l|}
\hline Skills & Test & N & Mean & $\begin{array}{l}\text { Std. } \\
\text { Deviation }\end{array}$ & T & df & $\begin{array}{l}\text { Sig. } \\
\text { tailed) }\end{array}$ & (2- \\
\hline $\begin{array}{l}\text { Effectively respond to the } \\
\text { writing task }\end{array}$ & Pre & 16 & 12.81 & 2.562 & 8.733 & 15 & .000 & $46.4 \%$ \\
\cline { 2 - 9 } & Post & 16 & 18.75 & 2.236 & & & & \\
\hline Well-organized, & Pre & 16 & 11.56 & 2.394 & 6.249 & 15 & .000 & $46.0 \%$ \\
\hline
\end{tabular}




\begin{tabular}{|c|c|c|c|c|c|c|c|c|}
\hline Skills & Test & $\mathrm{N}$ & Mean & $\begin{array}{l}\text { Std. } \\
\text { Deviation }\end{array}$ & $\mathrm{T}$ & df & $\begin{array}{l}\text { Sig. } \\
\text { tailed })\end{array}$ & Improvement \\
\hline $\begin{array}{l}\text { introduction, body, and } \\
\text { conclusion }\end{array}$ & Post & 16 & 16.88 & 2.500 & & & & \\
\hline \multirow{2}{*}{$\begin{array}{l}\text { Use of at least two } \\
\text { supporting sentences }\end{array}$} & Pre & 16 & 12.19 & 2.562 & 5.694 & 15 & .000 & $48.7 \%$ \\
\hline & Post & 16 & 18.13 & 2.500 & & & & \\
\hline \multirow{2}{*}{$\begin{array}{l}\text { Use of proper grammar, } \\
\text { spelling, and punctuation }\end{array}$} & Pre & 16 & 10.94 & 2.016 & 8.883 & 15 & .000 & $62.8 \%$ \\
\hline & Post & 16 & 17.81 & 2.562 & & & & \\
\hline \multirow{2}{*}{$\begin{array}{l}\text { Use of connectors, } \\
\text { transitional words }\end{array}$} & Pre & 16 & 9.38 & 3.096 & 7.261 & 15 & .000 & $77.9 \%$ \\
\hline & Post & 16 & 16.69 & 3.301 & & & & \\
\hline \multirow[t]{2}{*}{ Total } & Pre & 16 & 56.88 & 7.042 & $\begin{array}{l}18.19 \\
4\end{array}$ & 15 & .000 & $55.2 \%$ \\
\hline & Post & 16 & 88.25 & 4.359 & & & & \\
\hline
\end{tabular}

As Table 3 shows, the mean score for the students' responding effectively to the writing task before the experiment was 12.81 and after the experiment was 18.75, with an improvement of 46.4\%. Organizing the essay with an introduction, body, and a conclusion showed a mean score of 11.56 before the experiment and 16.88 after the experiment. The improvement in this technique was $46.0 \%$. The mean score of using supporting sentences in the body paragraphs before the experiment was 12.19 and after the experiment was 18.13. The improvement of the students in this skill was $48.7 \%$. The mean score of using proper grammar, spelling, and punctuation before the experiment was 10.94 , while it was 17.81 after the experiment, with an improvement of $62 \%$. Finally, the mean score of use of connectors and transitional words before the experiment was 9.38 and after the experiment was 16.69, with an improvement of $77 \%$.

Table 3 also shows the total result of the test before the experiment and after the strategy was applied. As shown in Table 3, the mean score for the students' essays before the experiment was 56.88. After the experiment, it was 88.25. The total improvement of students' writing was $55.2 \%$. Therefore, the results show that there was a significant difference $(\alpha \leq .05)$ between the scores of the students for both tests before and after the experiment. This indicates that the use of the guided writing strategy had a positive effect.

\section{Second Hypothesis}

Students in this study did not have positive attitudes toward the use of the guided writing strategy. To check this hypothesis, the mean score, standard deviation, and value of the direction were calculated, as shown in Table 4. 


\section{Dr. Khalid M. Alwahibee}

Table 4

Values of the Scores on the Questionnaire

\begin{tabular}{|l|l|l|l|l|l|}
\hline Answer & $\begin{array}{l}\text { Strongly } \\
\text { agree }\end{array}$ & Agree & Neutral & Disagree & $\begin{array}{l}\text { Strongly } \\
\text { Disagree }\end{array}$ \\
\hline Score & 5 & 4 & 3 & 2 & 1 \\
\hline
\end{tabular}

The value interpretations were adjusted as shown in Table 5.

Table 5

Title

\begin{tabular}{|l|l|}
\hline $\begin{array}{l}\text { Grade } \\
\text { Interpretation }\end{array}$ & Average Scores \\
\hline Very high & Averages between 4.20 and 5.00 \\
\hline High & Averages between 3.40 and less than 4.20 \\
\hline $\begin{array}{l}\text { Neutral } \\
\text { (Medium) }\end{array}$ & Averages between 2.60 and less than 3.40 \\
\hline Weak & Averages between 1.80 and less than 2.60 \\
\hline Very weak & Averages between 1.00 and less than 1.80 \\
\hline
\end{tabular}

Table 6

Arrangement of Statements According to the Mean, Standard Deviation, and Attitude Value for the Statements of the Questionnaire According to Opinions of Students in the Experimental Group

\begin{tabular}{|l|l|l|l|l|l||}
\hline Question & N & Mean & $\begin{array}{l}\text { Std. } \\
\text { Deviation }\end{array}$ & Rating & Ranking \\
\hline Q3 & 16 & 4.88 & 0.342 & $\begin{array}{l}\text { Strongly } \\
\text { Agree }\end{array}$ & 1 \\
\hline Q10 & 16 & 4.88 & 0.342 & $\begin{array}{l}\text { Strongly } \\
\text { Agree }\end{array}$ & 1 \\
\hline Q5 & 16 & 4.81 & 0.403 & $\begin{array}{l}\text { Strongly } \\
\text { Agree }\end{array}$ & 2 \\
\hline Q4 & 16 & 4.75 & 0.447 & $\begin{array}{l}\text { Strongly } \\
\text { Agree }\end{array}$ & 3 \\
\hline Q6 & 16 & 4.75 & 0.447 & $\begin{array}{l}\text { Strongly } \\
\text { Agree }\end{array}$ & 3 \\
\hline Q1 & 16 & 4.69 & 0.479 & $\begin{array}{l}\text { Strongly } \\
\text { Agree }\end{array}$ & 4 \\
\hline Q8 & 16 & 4.69 & 0.479 & $\begin{array}{l}\text { Strongly } \\
\text { Agree }\end{array}$ & 4 \\
\hline Q9 & 16 & 4.69 & 0.479 & $\begin{array}{l}\text { Strongly } \\
\text { Agree }\end{array}$ & 4 \\
\hline
\end{tabular}




\begin{tabular}{|l|l|l|l|l|l||}
\hline Question & $\mathrm{N}$ & Mean & $\begin{array}{l}\text { Std. } \\
\text { Deviation }\end{array}$ & Rating & Ranking \\
\hline Q2 & 16 & 4.56 & 0.629 & $\begin{array}{l}\text { Strongly } \\
\text { Agree }\end{array}$ & 5 \\
\hline Q7 & 16 & 4.50 & 0.516 & $\begin{array}{l}\text { Strongly } \\
\text { Agree }\end{array}$ & 6 \\
\hline All & 16 & 4.72 & 0.122 & $\begin{array}{l}\text { Strongly } \\
\text { Agree }\end{array}$ & \\
\hline
\end{tabular}

Table 6 indicates that students had very positive attitudes toward all 10 statements because the average fell between 4.20 and 5. The mean score for the total attitude of students' on the questionnaire was very high (4.72) and fell between 4.20 and 5.0. These results indicate that students had a positive attitude toward the use of the guided writing strategy in teaching essay writing.

\section{Discussion}

The findings of this experiment showed that using the guided writing strategy involving a template that provides guidelines for the students improved their essay writing. Table 3 shows that students improved on the many levels on which they were tested. In addition, they showed good improvement in the total score for their essays. The results of this study are in line with those obtained by Timayi (2015), who affirmed that the guided writing strategy improved the writing of the experimental group in her study, who had higher scores than the control group. The results were similar in this study, in which students showed higher scores after the experiment than before the experiment. Moreover, the findings in this study were in line with those of a study by Bachtiar and Sagala (2012), who emphasized that the use of the guided writing strategy resulted in higher scores in the writing classes and improved students' writing competence. Another study that confirms the results of this study was conducted by Anggara (2013), who applied the guided writing strategy for 61 students. The results showed a significant difference in favor of the experimental group, which indicated that students' writing improved. Moreover, Khatri (2014) examined the effectiveness of using guided writing in teaching composition for secondary school students. He used pretest and post test tools to collect the data. He taught students for 30 lessons. The results of his study are in line with those of this study because he found that guided writing activities were more effective in teaching composition.

The results of this study also revealed that the use of the guided writing template or strategy improved students' abilities in the five 


\section{Dr. Khalid M. Alwahibee}

elements (skills) that constituted the evaluation of their essays. For example, Table 3 indicates that students used connectors and transitional words better than before the experiment, with an improvement of $77.9 \%$. This could be due to the fact that students were able to memorize some words that show the sequence of an essay and use them at the beginning of each sentence. This result is emphasized by students' high responses to the third statement ("Using the guided writing template showed me how to use transitional words") of the attitude questionnaire, placing it in the first rank, as shown in Table 6. Use of proper grammar, spelling, and punctuation can be interpreted as the use of short and straightforward sentences; it was ranked second, with an improvement of $62.8 \%$. This result is emphasized by students' selection of statement 10 on the attitude questionnaire ("Using the guided writing template improved my punctuation, use of connectors, and grammar"), which came in the first rank (repeated). Before the experiment, most of the students would write one supporting sentence. However, with the guided writing template, they were trained with the help of the use of connectors and transitional words to use more than two supporting sentences. This resulted in it coming in the third position, with an improvement of $48.7 \%$. Students' choice on the attitude questionnaire supported this when the statement "The use of the guided writing template helped me to write good supporting sentences" came in the third position. With more training on using the guided writing template and help during their writing, students were able to respond to the writing topic, which resulted in it being ranked fourth among the skills, with an improvement of $46.4 \%$. This finding was supported by students' responses to the attitude questionnaire, which resulted in the statement "The guided writing strategy helped me respond effectively to the writing topic" being ranked fourth. The guided writing template encouraged the students to use a certain framework for the essay. Therefore, in the final test, students were able to write a well-organized essay with an introduction, body paragraphs, and a conclusion, with an improvement of $46.0 \%$. This was also supported by students' choice on the sixth statement of the attitude questionnaire, "I became aware of the proper format of the essay and can write a well-organized essay."

To conclude, the guided writing template (strategy) was proven to be effective in developing students' writing. In addition, it helped them organize their essays and use what was necessary to improve their final writing products. The guided writing strategy gave students a positive attitude toward writing. Students' attitude received a mean score of 4.72, which is considered very high. 


\section{Answering the Research Questions}

First question. The first research question was, "Is there any positive effect of using the guided writing template strategy on the performance of third-level essay writing class students?"

The answer is yes. The results show that there was a significant difference in the posttest for the group after the experiment was conducted, as shown in Table 3. The significance level was 0.000 for the total results of the posttest for the essay writing, which is less than the significance level of 0.05 . Therefore, there was a significant effect of using the guided writing strategy on students' essay writing.

Second question. The second question was, "If there were any positive effect on students' performance, how significant would it be?" The answer is yes, there was an effect. The students' essay writing improved by $55.2 \%$. This indicates that the guided writing strategy had a positive effect on students' essay writing.

Third question. The third question was, "Is there any positive effect on students' attitude toward the use of the guided writing strategy?" The answer is yes. The results of the attitude questionnaire showed that the mean score of the students' total writing grade was 4.72, which indicates a very high change. This also indicates that students recognized the positive effect of the strategy on their own essay writing.

Fourth question. The fourth question was, "Which part of students' essay writing was affected by this strategy?" All parts of essay development process were affected by the use of the guided writing strategy. This was clear from the improvement percentage, as shown in Table 3. This indicates that the guided writing strategy had an effect on students' overall essay writing.

\section{Conclusion}

The results of this study reveal that the use of the guided writing strategy is very effective in improving students' essay writing. The experiment proved that students who were weak in essay writing found it very helpful for them, and therefore, they were able to write better than before. Thus, this study presents some recommendations and suggestions based on the findings.

\section{Recommendations}

Based on the findings of this research, a few recommendations can be drawn:

- Essay writing teachers for level three should encourage their students to use the guided writing template found on the website of the assigned book.

- Teachers should initially adopt the guided writing strategy when teaching either paragraph-level or essay writing. 


\section{Dr. Khalid M. Alwahibee}

- Curriculum planners and administrators in the English departments should encourage all teachers to use this strategy because it is very effective.

- Senior or expert writing teachers should be allowed to give workshops to show the importance of using the guided writing strategy.

- The guided writing strategy helped students overcome difficulties; therefore, it is recommended that teachers make students practice a lot in and out of class.

\section{Suggestions}

This study was not comprehensive. Therefore, the following are suggested for future studies:

- Comparing female students to male students would be a good suggestion for future research.

- Comparing this strategy to another writing strategy to determine which is more effective would also be a good area of investigation.

- Investigating the effectiveness of this strategy on students at lower levels could be another area for future research.

- Conducting the same study with a greater number of students and for a longer period of time may result in better improvement, which could allow the study to be generalized. 


\section{References}

Amberg, J., \& Vause, D. (2010). American English: History, structure, and usage. City, State: Cambridge University Press.

Anggara, Y. (2013). The effectiveness of guided writing in improving the students' writing ability of the eighth grade students at SMP Negeri 2 Temon in the academic year of 2012/2013.

Bachtiar, M. P. D., \& Sagala, H (2012). Improving students' achievement in writing analytical exposition text through guided writing technique. Retrieved December 21, 2014 from http://jurnal.unimed.ac.id/2012/index.php/ellu/article/downloa d/359/166.

Brown, H. D. (2001). Teaching by principle: An interactive approach to language pedagogy. London, England: Longman.

Harmer, J. (2004). How to teach writing. Essex, England: Pearson Education Limited.

Holdich, C. E., \& Chung, P. W. H. (2003). A 'computer tutor' to assist children develop their narrative writing skills: Conferencing with HARRY. International Journal of Human-Computer Studies, 59(5), 631-669.

Hyland, K. (2003). Second language writing. New York, NY: Cambridge University Press.

Irawati, L. (2015). Applying cultural project based learning to develop students' academic writing. DINAMIKA ILMU, 15(1), pp-pp.

Khatri, D. (2014). Effectiveness of guided writing in teaching composition. Journal of NELTA Surkhet, 4(xx), pp-pp.

Lili, Z. (2015). On writing strategies of enhancing students' writing skills. Higher Education of Social Science, 9(6), 70-74. doi:10.3968/8069.

Ontario Education. (2005). A guide to effective instruction in writing. New York, NY: The Ontario Ministry of Education.

Saud, W. I. (2015). Cohesion in the descriptive writing of EFL undergraduate. International Journal of Humanities and Cultural Studies, 2(2), pp-pp.

Lan, Y., Hung, C., and Hsu, H. (2011). Effects of guided writing strategies on students' writing attitudes based on media richness theory. The Turkish Journal of Educational Technology, 10(4), pp-pp.

Lee, L. (1994). L2 writing: Using pictures as a guided writing environment. Paper presented at the Rocky Mountain Modern Language Association Conference, State University of New York, Plattsburgh.

Lidvall, C. (2008). Get real: Instructional implications for authentic writing activities. Retrieved from http://hdl.handle.net/1803/789.

Timayi, C. (2015). Impact of guided writing strategies on junior secondary school students' writing competence in Kaduna State, Nigeria. International Journal of Research and Information Science, 2(3), pp-pp.

Yang, J. C., Ko, H. W., \& Chung, I. L. (2005). Web-based interactive writing environment: Development and evaluation. Educational Technology and Society, 8(2), 214-229

Weigle, S. C. (2002). Assessing writing. Cambridge, United Kingdom: Cambridge University Press. 


\section{Dr. Khalid M. Alwahibee}

Guided Writing Template

Appendix A

Name of student:

Date:

Title of your topic:

\begin{tabular}{|c|c|c|}
\hline $\begin{array}{l}\text { Introductory } \\
\text { paragraph }\end{array}$ & $\begin{array}{l}\text { Transition } \\
\text { connectors }\end{array}$ & Essay \\
\hline $\begin{array}{l}\text { Use Hook sentence: } \\
\text { It could be a shocking } \\
\text { sentence, statistical } \\
\text { sentence, surprising } \\
\text { sentence. } \\
\text { Background: } \\
\text { Tell why the issue } \\
\text { (topic) is important and } \\
\text { to who it is important } \\
\text { Thesis statement: } \\
\text { Take a side on the issue } \\
\text { (topic). } \\
\text { perspective only. }\end{array}$ & $\begin{array}{l}\text { Showing contrast: But, } \\
\text { yet, whereas, even } \\
\text { though, although, } \\
\text { however, in contrast, } \\
\text { unlike. } \\
\text { Reasons: So, because. } \\
\text { Results: Therefore, } \\
\text { consequently. } \\
\text { Adding information: } \\
\text { And, in addition, } \\
\text { moreover. } \\
\text { Similarities: Similarly, } \\
\text { likewise, like. } \\
\text { Relationship: While, } \\
\text { when, before, after, after } \\
\text { that, meanwhile, then, } \\
\text { finally. } \\
\text { Conclusions: } \\
\text { conclusion, in summary. }\end{array}$ & 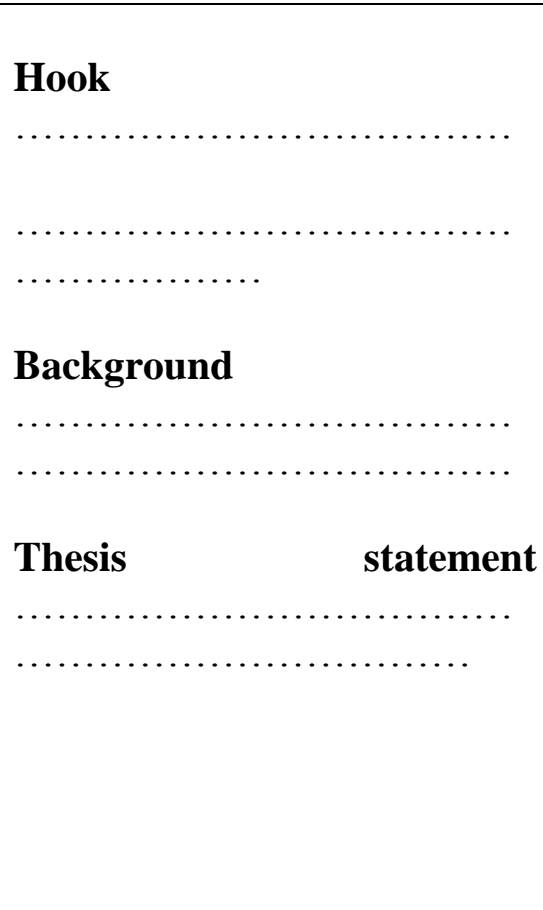 \\
\hline $\begin{array}{l}\text { First body paragraph } \\
\text { Topic sentence (should } \\
\text { have a controlling idea). } \\
\text { Short. } \\
\text { Use connector after the } \\
\text { topic sentence. Use } \\
\text { good } \\
\text { punctuation. } \\
\text { Write three supporting } \\
\text { sentences. } \\
\text { Use conclusion } \\
\text { sentence for the } \\
\text { paragraph. } \\
\text { Summarize what you } \\
\text { have said. }\end{array}$ & $\begin{array}{l}\text { Use appropriate } \\
\text { transition at the } \\
\text { beginning. } \\
\text { Depends on the type of } \\
\text { essay you are writing. }\end{array}$ & 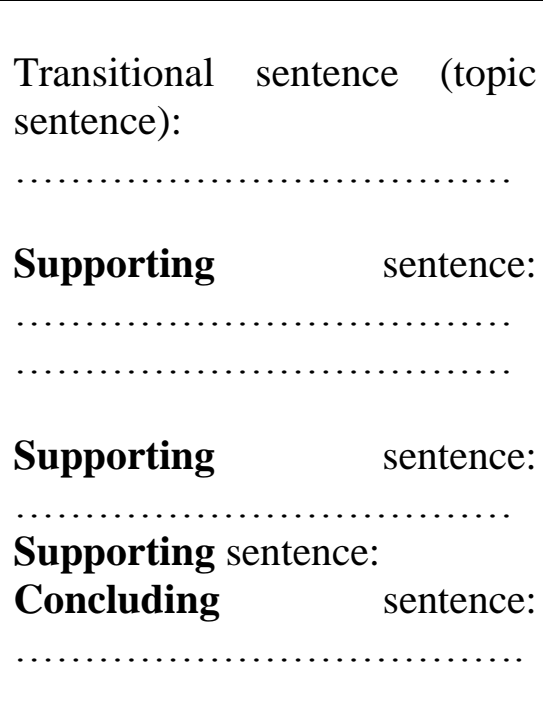 \\
\hline $\begin{array}{l}\text { Second body } \\
\text { paragraph } \\
\text { Topic sentence (should } \\
\text { have a controlling idea). } \\
\text { Short. }\end{array}$ & $\begin{array}{l}\text { Use appropriate } \\
\text { transition at the } \\
\text { beginning. }\end{array}$ & $\begin{array}{l}\begin{array}{l}\text { Transitional } \\
\text { sentence): }\end{array} \\
\ldots \ldots \ldots \ldots \ldots \ldots \ldots \ldots \ldots \ldots \ldots \ldots \\
\text { Supporting } \\
\ldots \ldots \ldots \ldots \ldots \ldots \ldots \ldots \ldots \ldots \ldots\end{array}$ \\
\hline
\end{tabular}




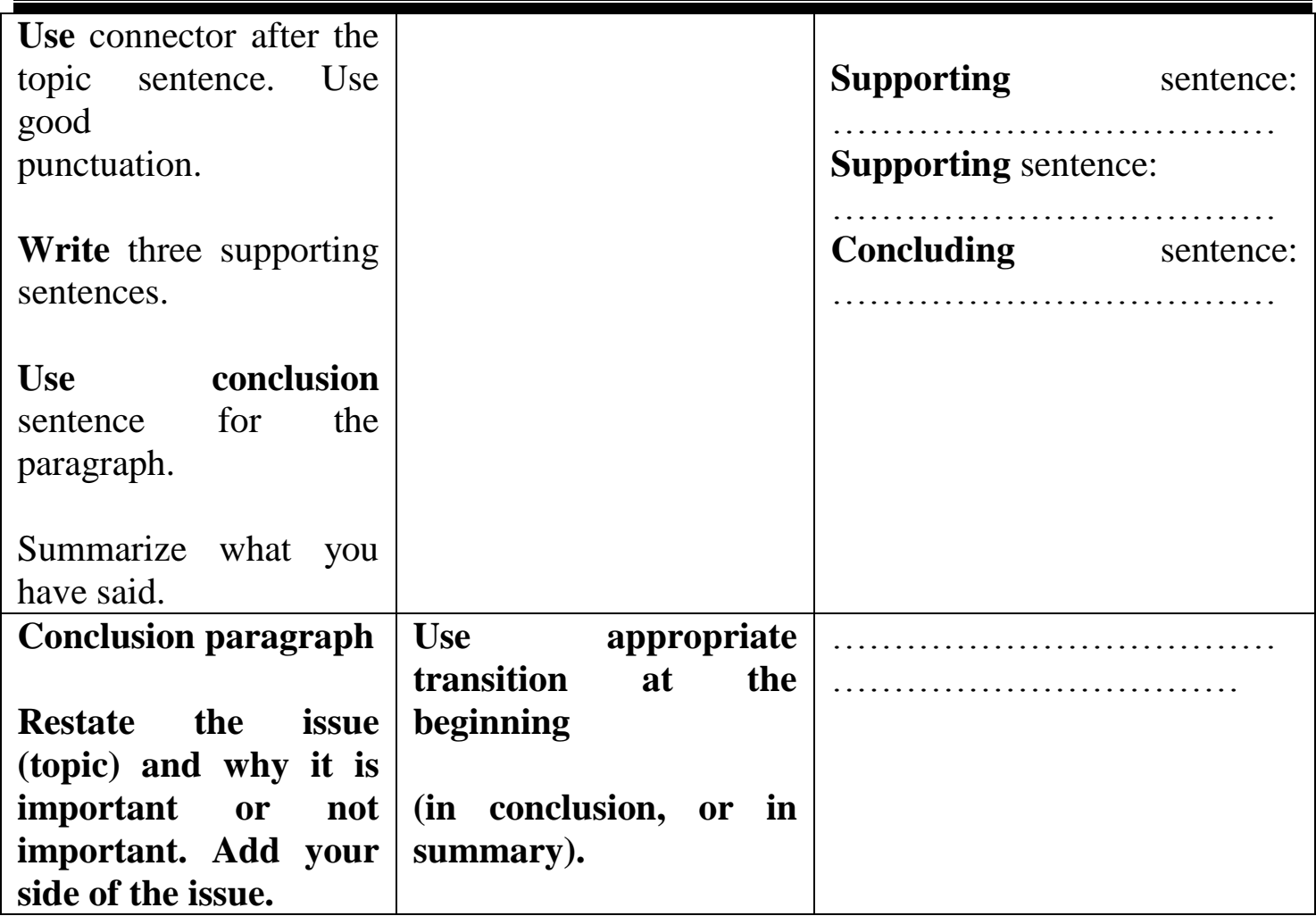




\section{Dr. Khalid M. Alwahibee}

Appendix B

Attitude Questionnaire on the Use of the Guided Writing Strategy

\begin{tabular}{|l|l|l|l|l|l|}
\hline Statement & $\begin{array}{l}\text { Strongly } \\
\text { agree }\end{array}$ & Agree & Neutral & Disagree & $\begin{array}{l}\text { Stron } \\
\text { gly } \\
\text { disagr } \\
\text { ee }\end{array}$ \\
\hline $\begin{array}{l}\text { 1. Following the guidelines of } \\
\text { the template assisted me in } \\
\text { building the body paragraphs. }\end{array}$ & & & & & \\
\hline $\begin{array}{l}\text { 2. Using the guided writing } \\
\text { template made me aware of how } \\
\text { to write a good introduction. }\end{array}$ & & & & & \\
\hline $\begin{array}{l}\text { 3. Using the guided writing } \\
\text { template showed me how to use } \\
\text { transitional words. }\end{array}$ & & & & & \\
\hline $\begin{array}{l}\text { 4. The guided writing strategy } \\
\text { helped me respond effectively to } \\
\text { the writing prompt. }\end{array}$ & & & & & \\
\hline $\begin{array}{l}\text { 5. The use of the guided writing } \\
\text { template helped me to write } \\
\text { good supporting sentences. }\end{array}$ & & & & & \\
\hline $\begin{array}{l}\text { 6. I became aware of the proper } \\
\text { essay format and can write a } \\
\text { well-organized essay. }\end{array}$ & & & & & \\
\hline $\begin{array}{l}\text { 7. I prefer that the teacher uses } \\
\text { the guided writing strategy } \\
\text { rather than traditional teaching. }\end{array}$ & & & & & \\
\hline $\begin{array}{l}\text { 8. After being trained on the use } \\
\text { of the guided writing strategy, I } \\
\text { think I am able to write a good } \\
\text { essay without a template. }\end{array}$ & & & & & \\
\hline $\begin{array}{l}\text { 9. I think I missed a lot of things } \\
\text { by not using the online template }\end{array}$ & & & & & \\
\hline $\begin{array}{l}\text { 10. Using the guided writing } \\
\text { template improved my } \\
\text { punctuation, use of connectors, } \\
\text { and grammar. }\end{array}$ & & & & & \\
\hline
\end{tabular}

